\title{
GRICE'S COOPERATIVE PRINCIPLE VIOLATION IN THE SECOND PRESIDENTIAL DEBATE BETWEEN HILLARY CLINTON AND DONALD TRUMP
}

\author{
Yoan Lodari \\ Universitas Bengkulu, \\ e-mail : yoanlodari@yahoo.com \\ Kasmaini \\ Universitas Bengkulu, \\ e-mail : kasmainiunib@gmail.com \\ Syafrizal Sabarudin \\ Universitas Bengkulu, \\ e-mail: syafrizal@unib.ac.id
}

\begin{abstract}
The aims of this research were to investigate kinds of maxims violated by the speakers and to investigate possible purposes of violations applied by the speakers. This research was conducted as qualitative descriptive study. The corpus of this research was Second Presidential transcript debate. The transcript was put into a checklist table and analyzed by Grice's theory of Cooperative Principle. The results of this study showed that both Hillary Clinton and Donald Trump violated all maxims, with 75 violations by Hillary Clinton and 174 violations by Donald Trump. The most violated maxim by both speakers was maxim of quantity and the less violated maxim was maxim of manner. Moreover, the result showed the least possible purposes of violation by the speakers was to build positive political image towards hearer.
\end{abstract}

Key words: Violation Maxims, Cooperative Principle, Debate.

\section{INTRODUCTION}

A conversation is considered to be cooperative if the interlocutor understand what the speaker means. In the daily life, a conversation is usually happened not effective. As follows the rule of Cooperative principle, perhaps there is no misleading of the utterance meaning, therefore the conversation will run well. A philosopher, Paul Grice pointed out the four maxims which consisted in the Cooperative Principle (1975: 45). Those are maxim of quality, the rule of maxim of quality requires us to try to make a contribution which is true. Second, is maxim of quantity which has a rule that we should give the right amount of information. Third, maxim of relation, the rule of this maxim is to be relevant. And the last is maxim of manner, the rule of this maxim is to be perspicuous. A maxim is failed to fulfill by the speaker if the speaker does not follow the rule of Cooperative Principle.

Thomas (2013; p. 64) proposed that there are five ways of failing to observe a maxim from 
Grice (1975; p. 49), one of them is violating a maxim. If a speaker violates a maxim, therefore in some cases, one will be liable to mislead (Grice, 1989; p. 30).

If a speaker violates maxim of quality, they are not trying to give a true contribution. For example:

A : David, can you help me? (holding many books at once)

B : One attack left, I will finish the enemies.

(looking at his mobile phone)

$B$ knows that $A$ wanted his help, but $B$ distorts the question given from $A$ and informs her about his activity. There are several meaning from $B$ answer, first $B$ asked $A$ to wait him until he finished the game. Second, $B$ did not want to help $A$. If $B$ follows the rule of maxim of quality, $B$ should answer A's question by saying Yes, I can or No, I cannot help you.

If a speaker violates maxim of quantity, they must be give more or less than it is required. For example:

A : How many times you eat per day?

B : Three.

$A$ was asked $B$ to know how many times $B$ eat per day. B answered $A$ 's question by just saying three. $B$ gave information too short. This is a violation of maxim quantity. If $B$ follows the rule of maxim of quantity, B should answers "I eat three times per day".

If a speaker violates maxim of relation, they must be not relevant. For example:

A : You are different with him, I knew it.
B : Let's we talk about you.

As can be seen, $B$ avoids talking about the statement given by $A$. B became not relevant in this conversation. If $B$ follows the rule of maxim of relation, $A$ should responds to the statement given, not avoid talking about it.

If a speaker violates maxim of manner, they must be perspicuous. For example:

A stated an utterance, "Everything you did to me is nothing. You are just a tiny little dust in this world!". This utterance is violation of maxim of manner. A exaggerated things. If $A$ follows the rule of maxim of manner, A should not use the word tiny little dust, instead of dust. Because we have already known that dust is tiny.

In fact, violation of maxims happens when individuals intentionally avoid the use of maxims in their own purpose of communication, which causes misunderstanding on participants. Tupan and Natalia (2008; p. 68) were already set up a violation markers based on Grice's theory of Cooperative Principle. They were also proposed several reasons people violates maxims, such as save face, cover up the secret, hide the truth, to please the hearer, and to envy other people.

Even if ones already knew about the principles, sometimes this violation happened, including on debate.

Debate is a discussion between two or more participants who have different arguments or opinions on the discussed topic. According to Bluedorn (2008) there are four kinds 
of debate, they are parliamentary debate, Lincoln-Douglas Debate or Value Debate, Cross Examination Debate, and Academic Debate. Last year in 2016, the United States has elected their new president. Before the electing day, the presidential debate were sponsored by the nonpartisan and nonprofit, Commission on Presidential Debates (CPD).

CPD (2016) mentioned three presidential and one vice presidential general election debates and the formats for the 90minute debates are designed to facilitate in-depth discussion of the leading issues facing the nation. This

\section{METHOD}

The type of this study was descriptive qualitative study. The corpus was Second Presidential transcript debate between Hillary Clinton and Donald Trump. The transcript was downloaded from New York Times website and edited by MiniLyrics application in order to add the timeline. The instrument was a checklist table. The data analyzed by using Grice's theory of Cooperative Principle. The researcher was helped by Coresearcher and two experts to judge the instrument to gain a valid data. To increase the reliability or dependability research, the

\section{RESULTS AND DISCUSSION}

The first research question was what kinds of violation of maxims are violated by the speakers. Here the research used the second presidential debate because it took town hall meeting form in which half of the questions will be posed directly by citizen participants and the other half will be posed by the moderator based on topics of broad public interest as reflected in social media and other sources.

The aims of this study were to investigate the kinds of maxim that violated and to investigate the possible purposes of violation done by Hillary Clinton and Donald Trump. By knowing the rule of maxims, perhaps there is no misleading while speak.

researcher conducted stepwise replication strategies taken from Ary, et al (2006). The analyzed data is called reliable if the result of similarity between researcher and co-researcher is more than $80 \%$. The formula used to count the reliability of this research:

$$
R=\frac{N_{1}}{N_{0}} X 100 \%
$$

Which :

$\mathrm{R}=$ Reliability

$N_{1}=$ The total of similar data results between researcher and co-researcher

$N_{0}=$ All of utterances

briefly amount of violations found from the data. 
Table 2. The Recapitulation of Violation Maxims Found

\begin{tabular}{|c|c|c|c|c|c|c|c|c|c|c|}
\hline \multirow{3}{*}{ Question } & \multicolumn{10}{|c|}{ Violation of maxim (times) } \\
\hline & \multicolumn{4}{|c|}{ Hillary Clinton } & \multirow{2}{*}{ Total } & \multicolumn{4}{|c|}{ Donald Trump } & \multirow{2}{*}{ Total } \\
\hline & Quality & Quantity & Relation & Manner & & Quality & Quantity & Relation & Manner & \\
\hline 1 & 1 & 2 & 2 & & 5 & & 1 & 2 & 1 & 4 \\
\hline 2 & & 2 & 1 & & 3 & 6 & 11 & 4 & 1 & 22 \\
\hline 3 & 1 & 2 & 2 & & 5 & 4 & 1 & 5 & 2 & 12 \\
\hline 4 & 3 & 1 & 4 & 1 & 9 & 5 & 6 & 2 & & 13 \\
\hline 5 & & 2 & & & 2 & 1 & 1 & 1 & 4 & 7 \\
\hline 6 & 1 & 2 & & 1 & 4 & 1 & & & & 1 \\
\hline 7 & & & & & 0 & 1 & 5 & & & 6 \\
\hline 8 & & 1 & & & 1 & & 1 & 1 & & 2 \\
\hline 9 & 1 & & 2 & & 3 & 5 & 6 & 2 & 4 & 17 \\
\hline 10 & 1 & 4 & 1 & & 6 & 3 & 2 & & & 5 \\
\hline 11 & 2 & 2 & 2 & 1 & 7 & & 1 & 1 & & 2 \\
\hline 12 & & 5 & 1 & & 6 & 5 & 9 & 3 & 1 & 18 \\
\hline 13 & 2 & 1 & & & 3 & & 3 & & 2 & 5 \\
\hline 14 & & & & & 0 & 1 & 5 & 2 & 3 & 11 \\
\hline 15 & 1 & 1 & & & 2 & 2 & 1 & 1 & & 4 \\
\hline 16 & & 3 & 1 & & 4 & 2 & 3 & 3 & 4 & 12 \\
\hline 17 & 1 & 1 & & 1 & 3 & 2 & 2 & & 1 & 5 \\
\hline 18 & & 4 & 1 & & 5 & 3 & 5 & 6 & 2 & 16 \\
\hline 19 & & 2 & 1 & & 3 & 2 & & 1 & & 3 \\
\hline 20 & & 3 & & & 3 & & 3 & & 3 & 6 \\
\hline 21 & & & 1 & & 1 & & 3 & & & 3 \\
\hline Total & 14 & 38 & 19 & 4 & 75 & 43 & 69 & 34 & 28 & 174 \\
\hline Percentage & $19 \%$ & $51 \%$ & $25 \%$ & $5 \%$ & $100 \%$ & $24.7 \%$ & $39.7 \%$ & $19.5 \%$ & $16.1 \%$ & $100 \%$ \\
\hline
\end{tabular}

As can be seen on the table above, there were 21 questions found by the researcher in the second presidential debate transcript. Those questions were numbered based on the question given by audiences and moderators also each questions gave different context. The researcher found that there were 75 violations by Hillary Clinton. From 75 violations found. There were 38 violations of maxim of quantity, 19 violations of maxim of relation, 14 violations of maxim of quality, and 4 violations of maxim of manner. On the other hand, the researcher found 174 violations by Donald Trump. From 174 violations found, there were 69 violations of maxim of quantity, 43 violations of maxim of quality, 34 violations of maxim of relation, and 28 violations of maxim of manner.

Furthermore, the table above answered the first research question. The result showed that both Hillary Clinton and Donald Trump violated all the maxims. The most violation did by the speakers was maxim of quantity (Hillary Clinton 51\%, Donald Trump 39.7\%). And it was followed by violation of 
maxim of quality (Hillary Clinton 19\%, Donald Trump 24.7\%) and maxim of relation (Hillary Clinton 25\%, Donald Trump19.5\%). On the other hand, violation of maxim of manner was less done by the speakers (Hillary Clinton 5\%, Donald Trump16.1\%).

Kinds of Maxims Violations by Both Speakers in the Data

There were many violations occurred in the data. Here the examples of violation for each maxims.

\section{Violation of maxim of quality}

The speaker failed to observe maxim of quality if the speaker lies or says something that is believed to be false, the speaker does irony or makes ironic and sarcastic statement, denies something, and distorts information (Tupan and Natalia (2008 p. 68)).

Here the following example:

\section{Question 4}

[24:27.24]COOPER: Secretary

Clinton, you can respond. Then we have to move on to an audience question.

[24:29.42]CLINTON: Look, it's just not true. And so please, go to... [24:33.80]TRUMP: Oh, you didn't delete them?

[24:34.92]COOPER: Allow her to respond, please.

[24:35.92]CLINTON: It was personal e-mails, not official.

[24:37.24]TRUMP: Oh, 33,000? Yeah.

[24:38.49]CLINTON: Not - well, we turned over 35,000 , so...

[24:40.30]TRUMP: Oh, yeah. What about the other 15,000?
Analysis:

In Question 4 talked about the way Hillary Clinton handles her e-mail. The bold excerpt above showed that Hillary Clinton denied something and it was one of the ways to violate maxim of quality. She denied Donald Trump statement that she has deleted 33,000 e-mails. Moreover, the seemed purpose of violating maxim quality was Hillary Clinton trying to save her face.

\section{Violation of maxim of quantity}

The speaker failed to observe maxim of quantity if the speaker talks not to the point, uninformative, talks too short or too much, and repeats certain words (Tupan and Natalia (2008 p. 68)).

Here the following example:

Question 8

[33:46.08]GORBAH HAMED: Hi. There are 3.3 million Muslims in the United States, and I'm one of them. You've mentioned working with Muslim nations, but with Islamophobia on the rise, how will you help people like me deal with the consequences of being labeled as a threat to the country after the election is over?

[34:05.21]RADDATZ: Mr. Trump, you're first.

[34:06.77]TRUMP: Well, you're right about Islamophobia, and that's a shame. But one thing we have to do is we have to make sure that because there is a problem. I mean, whether we like it or not, and we could be very politically correct, but whether we like it or not, there is a problem. And we have to be sure that Muslims come in and report when they see something going on. 
When they see hatred going on, they have to report it. As an example, in San Bernardino, many people saw the bombs all over the apartment of the two people that killed 14 and wounded many, many people. ...

As we remembered on the theory proposed by Grice, the rule of maxim quantity was giving the right amount of information. In Question 8 asked by Gorbah Hamed was asking about how Donald Trump helps people like him to deal with the consequences of being labeled as a threat to the country after the election over. The bold excerpts above showed that Donald Trump violated maxim of quantity by talking or answering the question not to the point. If Donald Trump followed the rule of Cooperative Principle, he should have mentioned the steps to help Gorbah Hamed and for many people like him. The seemed purpose of violating maxim of quantity by Donald Trump was control information.

\section{Violation of Maxim of Relation}

The speaker fails to observe maxim of relation if the speaker makes the conversation unmatched with topic, the speaker changes conversation topic abruptly, the speaker avoid talking about something, hides something or hides a fact, and does wrong causality (Tupan and Natalia (2008 p. 68)).

Here the following example:

\section{Question 10}

[43:58.45]RADDATZ: Thank you, Mr. Trump. I want to move on. This next question from the public through the Bipartisan Open Debate Coalition's online forum, where Americans submitted questions that generated millions of votes. This question involves WikiLeaks release of purported excerpts of Secretary Clinton's paid speeches, which she has refused to release, and one line in particular, in which you, Secretary Clinton, purportedly say you need both a public and private position on certain issues. So, Tu (ph), from Virginia asks, is it OK for politicians to be two-faced? Is it acceptable for a politician to have a private stance on issues? Secretary Clinton, your two minutes.

[44:43.24]CLINTON: ... And, yes, President Lincoln was trying to convince some people, he used some arguments, convincing other people, he used other arguments. That was a great - I thought a great display of presidential leadership.

But, you know, let's talk about what's really going on here, Martha, because our intelligence community just came out and said in the last few days that the Kremlin, meaning Putin and the Russian government, are directing the attacks, the hacking on American accounts to influence our election. And WikiLeaks is part of that, as are other sites where the Russians hack information, we don't even know if it's accurate information, and then they put it out. ...

In Question 10, the question was is it okay for politician to be two-faced and is it acceptable for a politician to 
have private stance on issues. The bold excerpts above showed that Hillary Clinton violated maxim of relation by changing conversation topic abruptly because the rule of maxim relation is being relevant. Hillary Clinton changed the topic to Kremlin, Putin and Russian government that support Donald Trump to become a president. Then the seemed purpose of violating maxim of relation by Hillary Clinton was to bring news for hearer.

\section{Violation of Maxim of Manner}

The speaker fails to observe maxim of manner if the speaker uses ambiguous language, the speaker exaggerates thing, the speaker uses slang in front of people who do not understand it, and if the speaker's voice is not loud enough (Tupan and Natalia (2008 p. 68)).

Here the following example:

\section{Question 12}

[58:56.80]TRUMP: Excuse me.

Because she has been a disaster as a senator. A disaster.

The bold excerpt above showed that Donald Trump exaggerated thing. As Tupan and Natalia set up on the violation markers, the speaker violates maxim of manner if the speaker exaggerates thing. Therefore, Donald Trump violated maxim of manner by saying that she has been a disaster as senator. The seemed purpose of the violation did by Donald Trump was to build positive image over the public.

The second research question was what seemed to be the purposes of violation maxims applied by the speakers. The second research question was focused on the seemed purpose of maxims violation did by the speakers. There were several seemed purposes found by the researcher. Those are convincing hearer, face saving, controlling information, giving complete answer, building hearer's belief, building positive political image and bringing news for hearer. After analyzed the data, it can be seen that the overall reason of violated maxims by Hillary Clinton and Donald Trump was trying to make positive image about them over the hearer.

Table 3. The Amount of the Way Hillary Clinton Violates Maxim

\begin{tabular}{|c|c|c|c|c|c|c|c|c|c|c|c|c|c|c|c|c|}
\hline \multirow{3}{*}{ Question } & \multicolumn{15}{|c|}{ The way speaker violates maxim (times) } & \multirow{3}{*}{$\begin{array}{c}\mathrm{T} \\
\mathrm{o} \\
\text { ta } \\
1\end{array}$} \\
\hline & \multicolumn{4}{|c|}{ Quality } & \multicolumn{5}{|c|}{ Quantity } & \multicolumn{4}{|c|}{ Relation } & \multicolumn{2}{|c|}{ Manner } & \\
\hline & A & B & C & D & A & B & C & D & $\mathbf{E}$ & A & B & C & D & A & B & \\
\hline Q1 & 1 & & & & & & 1 & 1 & & 1 & 1 & & & & & 5 \\
\hline Q2 & & & & & & & & 2 & & & 1 & & & & & 3 \\
\hline Q3 & & 1 & & & & 1 & & 1 & & & & 1 & 1 & & & 5 \\
\hline Q4 & & 3 & & & & & 1 & & & 1 & 1 & 2 & & 1 & & 9 \\
\hline Q5 & & & & & & & 2 & & & & & & & & & 2 \\
\hline Q6 & & 1 & & & 1 & & 1 & & & & & & & 1 & & 4 \\
\hline
\end{tabular}




\begin{tabular}{|c|c|c|c|c|c|c|c|c|c|c|c|c|c|c|c|c|}
\hline Q7 & & & & & & & & & & & & & & & & 0 \\
\hline Q8 & & & & & 1 & & & & & & & & & & & 1 \\
\hline Q9 & & & 1 & & & & & & & & 2 & & & & & 3 \\
\hline Q10 & & & & 1 & 1 & 1 & 1 & 1 & & & 1 & & & & & 6 \\
\hline Q11 & & 1 & 1 & & 1 & & 1 & & & 1 & 1 & & & & 1 & 7 \\
\hline Q12 & & & & & 2 & 2 & 1 & & & & 1 & & & & & 6 \\
\hline Q13 & & 2 & & & 1 & & & & & & & & & & & 3 \\
\hline Q14 & & & & & & & & & & & & & & & & 0 \\
\hline Q15 & & 1 & & & & 1 & & & & & & & & & & 2 \\
\hline Q16 & & & & & 1 & & 2 & & & 1 & & & & & & 4 \\
\hline Q17 & & 1 & & & & & 1 & & & & & & & & 1 & 3 \\
\hline Q18 & & & & & & & 3 & & 1 & 1 & & & & & & 4 \\
\hline Q19 & & & & & & & 1 & & 1 & & 1 & & & & & 3 \\
\hline Q20 & & & & & 1 & & 2 & & & & & & & & & 3 \\
\hline Q21 & & & & & & & & & & 1 & & & & & & 1 \\
\hline TOTAL & 1 & 10 & 2 & 1 & 9 & 5 & 17 & 5 & 2 & 6 & 9 & 3 & 1 & 2 & 2 & $\begin{array}{l}7 \\
5\end{array}$ \\
\hline PERCN \\
TAGE
\end{tabular}

Notes:

Maxim of Quality :
A. distorts information
B. denies something
C. makes irony/ sarcastic statement
D. lies/ says something that believed to be false

Maxim of Quantity:
A. talks not to the point
B. uninformative
C. talks too much
D. repeats certain words

On contrary with Table 2 which shows the number of violation maxims did by speakers, Table 3 showed the way speaker violates maxims. As can be seen on the table above, there are 15 ways show that Hillary Clinton violated maxims. , the table above showed 15 ways of violation did by Hillary Clinton and the dominant way she used to violate maxims.
E. talks too short Maxim of Relation:

A. making conversation unmatched with topic

B. changes conversation topic

C. avoids talking about something

D. hides something/ hides fact Maxim of Manner

A. ambiguous language

B. exaggerates thing

The most violation way that Hillary Clinton used was talking too much, with the percentage about $22.6 \%$. Followed with the way Hillary Clinton violated maxim of quality by denying something, with the percentage about $13.3 \%$. The third dominant way used by Hillary Clinton was talking not to the point and changing conversation topic, with the percentage about $12 \%$. 
Table 4. The Amount of the Way Donald Trump Violates Maxim

\begin{tabular}{|c|c|c|c|c|c|c|c|c|c|c|c|c|c|c|c|c|}
\hline \multirow{3}{*}{$\begin{array}{l}\text { Questi } \\
\text { on }\end{array}$} & \multicolumn{15}{|c|}{ The way speaker violates maxim (times) } & \multirow{3}{*}{$\begin{array}{l}\text { Tot } \\
\text { al }\end{array}$} \\
\hline & \multicolumn{4}{|c|}{ Quality } & \multicolumn{5}{|c|}{ Quantity } & \multicolumn{4}{|c|}{ Relation } & \multicolumn{2}{|c|}{ Manner } & \\
\hline & A & B & C & D & A & B & C & D & E & A & B & C & D & A & B & \\
\hline Q1 & & & & & & & 1 & & & 1 & 1 & & & & 1 & 4 \\
\hline Q2 & & 3 & 2 & 1 & 1 & 1 & 4 & 5 & & & 3 & 1 & & & 1 & 22 \\
\hline Q3 & 1 & & 2 & 1 & & & & & 1 & 3 & 2 & & & & 2 & 12 \\
\hline Q4 & & 1 & 3 & 1 & & 2 & 2 & 1 & 1 & & 2 & & & & & 13 \\
\hline Q5 & & & 1 & & & & 1 & & & & 1 & & & & 4 & 7 \\
\hline Q6 & & & & 1 & & & & & & & & & & & & 1 \\
\hline Q7 & & & & 1 & 3 & 1 & 1 & & & & & & & & & 6 \\
\hline Q8 & & & & & 1 & & & & & & 1 & & & & & 2 \\
\hline Q9 & & 4 & & 1 & 2 & & & 4 & & & 2 & & & & 4 & 17 \\
\hline Q10 & & 2 & 1 & & & & & 2 & & & & & & & & 5 \\
\hline Q11 & & & & & & & & 1 & & 1 & & & & & & 2 \\
\hline Q12 & & 1 & & 4 & 1 & & 3 & 5 & 1 & 1 & 2 & & & & 2 & 18 \\
\hline Q13 & & & & & & & 3 & 1 & & & & & & & 2 & 5 \\
\hline Q14 & & & & 1 & & 1 & & 4 & & 1 & 1 & & & & 3 & 11 \\
\hline Q15 & & & 2 & & & & & 1 & & & 1 & & & & & 4 \\
\hline Q16 & & & 1 & 1 & & & 1 & 2 & & 2 & 1 & & & & 4 & 12 \\
\hline Q17 & & & & 2 & & & & 2 & & & & & & & 1 & 5 \\
\hline Q18 & & 1 & 1 & 1 & 4 & & 1 & & & 2 & 2 & 2 & & 1 & 1 & 16 \\
\hline Q19 & 1 & & 1 & & & & & & & 1 & & & & & & 3 \\
\hline Q20 & & & & & 1 & & 1 & 1 & & & & & & & 3 & 6 \\
\hline Q21 & & & & & 1 & & & 2 & & & & & & & & 3 \\
\hline TOTAL & 2 & 12 & 14 & 15 & 14 & 5 & 18 & 31 & 3 & 12 & 19 & 3 & 0 & 1 & 28 & $\begin{array}{c}17 \\
4\end{array}$ \\
\hline $\begin{array}{c}\text { PERCE } \\
\text { NTAGE }\end{array}$ & $\begin{array}{c}1.1 \\
\%\end{array}$ & $\begin{array}{c}6.9 \\
\%\end{array}$ & $\begin{array}{l}8.0 \\
4 \%\end{array}$ & $\begin{array}{c}8.6 \\
\%\end{array}$ & $\begin{array}{l}8.0 \\
4 \%\end{array}$ & $\begin{array}{c}2.8 \\
\%\end{array}$ & $\begin{array}{l}10 . \\
3 \%\end{array}$ & $\begin{array}{l}17 . \\
8 \%\end{array}$ & $\begin{array}{c}1.7 \\
\%\end{array}$ & $\begin{array}{c}6.9 \\
\%\end{array}$ & $\begin{array}{l}10 . \\
9 \%\end{array}$ & $\begin{array}{c}1.7 \\
\%\end{array}$ & $\begin{array}{l}0 \\
\%\end{array}$ & $\begin{array}{c}0.5 \\
\%\end{array}$ & $\begin{array}{c}16 . \\
09 \\
\%\end{array}$ & $\begin{array}{l}10 \\
0 \%\end{array}$ \\
\hline
\end{tabular}

Notes:

Maxim of Quality :
A. distorts information
B. denies something
C. makes irony/ sarcastic statement
D. lies/ says something that believed to be false

Maxim of Quantity
A. not to the point
B. uninformative
C. talks too much
D. repeats certain words

E. talks too short Maxim of Relation
A. Making conversation unmatched with topic
B. changes conversation topic
C. avoids talking about something
D. hides something/ hides fact Maxim of Manner
A. ambiguous language
B. exaggerates thing 
Similar with Table 3, on Table 4 the researcher found 15 ways that Donald Trump used to violate maxims. The table above shows the same 15 ways of violation did by Hillary Clinton and the dominant way Donald Trump used to violate maxims. Donald Trump violated maxims 31 times by repeating certain words, 28 times by exaggerating thing, and 19 times changing conversation topic.

The most violation way that Donald Trump used was repeating certain words, with the percentage about $17.8 \%$, followed with the way Donald Trump violated maxim of manner by exaggerating something with the percentage about $16.09 \%$. The third dominant way used by Donald Trump was changing conversation topic with the percentage about $10.9 \%$.

At least, the existence of violation of maxims is not always for bad purposes. People can do a violation for some reasons and situations. Then, education background, experiences, gender and control of emotions are aspects that influenced the speakers in debate to violate maxims.

\section{CONCLUSSION AND SUGGESTION}

The first research question of this study was to know what Grice's maxims were violated by the speakers. The answer was Hillary Clinton and Donald Trump violated all the maxims. In short, Donald Trump violated maxims more than Hillary Clinton. From the violations found, the most violation did by the speakers was maxim of quantity and violation of maxim of manner was the least done by the speakers.

The second research question focused on the seemed purpose of violation maxims did by the speakers. There were several seemed purposes found by the researcher and they were supported by previous study too. The seemed purposes of the violation were convincing hearer, face saving, controlling information, giving complete answer, building positive political image, building hearer's belief and bringing news for hearer. However, in this case both Hillary Clinton and Donald Trump seemed trying to make positive image about them over the hearer.

Based on the findings above, the researcher concluded that violation of maxims must be based on reasons. The social factors also influence the speaker to do violation, such as education background, experiences, gender and control of emotions. As long as the conversation runs well the violation of maxims can be accepted.

\section{REFERENCES}

Ary, D., Jacobs, L., Sorensen, C., \& Razavieh, A. (2006). Introduction to Research in Education: Eight Edition. Canada: Nelson Education, Ltd.

Bluedorn, Harvey. (2008). What is Debate. Available at: http://www.triviumpursuit.com/ speech debate/what is debate. php

Commission on Presidential Debate. (2016). Available at: 
http://debates.org/index.php?pa ge=2016debates

Crintsoft LLC. (2015).What is MiniLyrics?

Available at:

http://www.crintsoft.com/MiniLyric s.htm

Grice, H. P. (1975). Logic and Conversation. In $\mathrm{P}$ Cole and J. Morgan (eds), Speech Acts (Syntax and Semantics, Volume 3). New York: Academic Press, 113- 28.

Nisya, Anur. (2008). The Cooperative Principles in Debate. S1 Thesis.
Universitas

Pendidikan

Indonesia.

Tupan, Anneke H. and Natalia, Helen. (2008). The Multiple Violations of Conversational Maxims in Lying Done by the Characters in Some Episodes of Desperates Housewives. Petra Christian University: Surabaya, Indonesia.

Zaman, Fahrus. (2010). Flouts of the Cooperative Principle Maxims in SBY's Interviews. S2 Thesis. Universitas pendidikan Indonesia. 